\title{
Kebijakan Talent Scouting Jabatan Administator dan Pengawas Pemerintah Provinsi Jawa Tengah
}

\author{
Herru Setiadhie $^{1}$, Galih Wibowo ${ }^{2}$ \\ 1Program Studi Administrasi Publik, Fakultas Ilmu Sosial dan Ilmu Politik, Universitas \\ Diponegoro, Semarang \\ 2Pemerintah Provinsi Jawa Tengah, Semarang
}

\begin{abstract}
Every organization cannot be separated from change. Change is also an important aspect of public organizations or bureaucracy in local governments policy. One of the phenomenal changes implemented by the local government is the concept of employee promotion or widely known as job auctions. Central Java Provincial Government became one of the pioneers in the implementation of open promotion through the concept of talent scouting for the position of administrator and supervisor. Context, content, process, leadership and results are important indicators of change to see the extent to which talent scouting has been successfully implemented by the Central Java Provincial Government. Basically, the changes implemented must be inline with the vision of change and with other related concept changes.
\end{abstract}

Keywords: policy, talent scouting, Central Java Provincial government, change.

\section{Pendahuluan}

Setiap organisasi mengalami dinamika, tak luput pula organisasi publik pasti menghadapi perubahan. Perubahan bisa disebabkan karena oleh faktor internal seperti penyesuaian visi, kebutuhan ekspansi dan sebagainya, ataupun karena factor eksternal seperti tuntutan regulasi pemerintah dan sebagainya. Faktor eksternal umumnya berhubungan dengan kekuatan yang mendorong terjadinya perubahan, sedangkan faktor internal berkenaan dengan kebutuhan akan perubahan (Wibowo, 2016; Armenakis \& Bedeian, 1999).

Perubahan pada organisasi publik dapat dikategorikan menjadi 2 (dua) terminology, yaitu reform (reformasi) dan change (perubahan) (Christensen et.all, 2007; Tom Christensen, Per Laegreid, Paul G Roness, 2007). Reformasi (reform) ialah upaya aktif dan disengaja pemimpin politik dan administrasi untuk mengubah fitur struktural atau 
budaya organisasi. Sedangkan perubahan (change) adalah proses bertahap dalam organisasi, berlangsung sebagai kegiatan rutin dan sedikit demi sedikit, namun terkadang bisa juga berupa pergolakan yang tiba-tiba dan kuat dimana potensinya telah terbangun dalam periode waktu yang lebih lama.

Rusaw (Rusaw, 2005) menyatakan bahwa merubah birokrasi organisasi publik sulit karena adanya tekanan pada pimpinan dan bawahan organisasi untuk bekerja lebih efektif dan efisien menggunakan sumberdaya yang semakin terbatas. Goliembiewski (Carol Rusaw, 2007) mencatat lima kendala struktural yang membedakan perubahan organisasi sektor publik dengan sektor privat, yaitu :

[1] organisasi publik mengandung "iron quadragle" atau besi segiempat pengambilan keputusan yaitu administrasi, eksekutif, legislatif, dan media massa yang saling terkait;

[2] organisasi publik memiliki berbagai kepentingan dan struktur imbalan, sehingga justru mengutamakan untuk memuaskan semua pemangku kepentingan yang relevan sehingga sulit untuk mengidentifikasi kebutuhan yang tepat untuk perubahan;

[3] sebagai birokrasi pemerintah yang berada dalam system desentralisasi dan otonomi, organisasi tidak memiliki kekuatan terpusat, sehingga lebih responsif terhadap tekanan kekuasaan pemerintah daera, kementerian hingga pemerintah pusat;

[4] Sebagai organisasi publik banyak diawasi oleh kekuasaan politis dengan berbagai keahlian, minat, tujuan dan belum tentu sebagai profesional, sehingga hal ini mempersulit komunikasi dan koordinasi untuk mengambil kebijakan dan membatasi fleksibilitas pengambilan keputusan yang terdesentralisasi;

[5] Pondasi legislatif administrasi publik menghasilkan rentang kendali yang sempit, menekankan keteraturan prosedural daripada keterbukaan dalam menyelesaikan masalah, dan mencampurkan politik dan manajemen.

Perubahan organisasi publik juga dihadapkan pada beberapa tantangan berupa penolakan atau resistensi. Resistensi muncul karena tidak sesuai dengan apa yang diharapkan. Robbins \& Judge (2013)(Stephen P Robbins, 2013) menyatakan bahwa banyak agen perubahan gagal karena anggota organisasi menolak (resisten) terhadap perubahan karena dilihat sebagai sesuatu yang mengancam. Sebuah studi menunjukkan bahwa ketika karyawan ditunjukkan data yang menyarankan agar mereka perlu berubah, mereka akan mencari data apa pun yang mereka dapat temukan yang menunjukkan bahwa mereka baik-baik saja dan tidak perlu diubah. Armenakis \& Bedeian (Armenakis \& 
Bedeian, 1999) berpendapat bahwa kesiapan perubahan merupakan tahap penting dalam menentukan keberhasilan upaya perubahan. Kesiapan perubahan menunjukkan modal dasar untuk perilaku yang akan terjadi baik resistensi atau mendukung upaya perubahan.

Banyak terdapat tantangan dan kendala dalam perubahan organisasi publik. Namun Cunningham dan Kempling (Cunningham \& Kempling, 2009) justru menyebut bahwa perubahan sektor publik mungkin tidak lebih sulit daripada perubahan yang terjadi di sektor swasta. Hal ini sejalan dengan optimism birokrasi yang disebutkan oleh Aykac \& Metin (Aykac \& Metin, 2012).

Masa depan organisasi public (The future of public organizations) menunjukkan bahwa organisasi publik sebagai komponen terpenting dari administrasi publik sangat dipengaruhi oleh proses perubahan, dan terkait hal tersebut maka Aykac dan Metin (Aykac \& Metin, 2012) memprediksikan masa depan yang akan dihadapi organisasi publik adalah pertama struktur organisasi yang fleksibel akan meningkat, kedua birokrasi tidak akan berkurang meskipun ada peningkatan fleksibilitas, ketiga perdebatan tentang kualitas layanan publik akan terus berlanjut, keempat kekuatan teknologi informasi akan semakin ditekankan, dan kelima kualitas pemimpin administrator dalam administrasi publik akan semakin diperhatikan. Proyeksi masa depan tersebut tentunya menuntut organisasi publik agar memiliki kemampuan melakukan perubahan menyesuaikan dengan kondisi yang dihadapi.

Dualisme

pendapat menyatakan bahwa sector publik susah berubah kontrak dengan optimism pendapat lain yang menyatakan perubahan tetap akan terjadi, menyisakan pertanyaan tentang bagaimana manajemen perubahan organisasi publik berjalan. Melihat beragam penelitian diatas, maka managemen perubahan pada sector publik menjadi sangat penting untuk diperhatikan. Salah satu tema penting yang perlu dibahas dalam manajemen perubahan adalah factor pemimpin administrasi, sebagaimana penelitian Aykac dan Metin (Aykac \& Metin, 2012).

Mengingat kualitas dari pemimpin administrasi semakin diperhatikan, maka beragam upaya telah berjalan untuk memilih pemimpin birokrasi. Setiap daerah memiliki inovasi masing-masing. Dimulai dengan istilah lelang jabatan yang popular di Pemrov. DKI Jakarta periode kepemimpinan Jokowi Ahok, maupun talent scouting dan Seleksi Terbuka yang diselenggarakan Pemprov. Jateng mulai tahun 2014, hingga Promosi Terbuka yang diselenggarakan oleh Pemprov. Jabar (Wibowo \& Soeprihattanto, 2020). Pemerintah Provinsi Jawa Tengah merupakan salah satu lokus yang menarik untuk diteliti karena pemerintah dengan reformasi birokrasi terbaik tahun 2017, dimana salah satu aspek reformasi yang dijalankan adalah 
terkait promosi pegawai melalui talent scouting. Belum banyak penelitian yang menyangkut tentang birokrasi di Jawa Tengah, dan masih sangat sedikit jurnal penelitian tentang talent scouting, karena regulasi resmi yang berlaku baru terbit tahun 2017, sedangkan penelitian ini berlangsung tahun 2019.

Dengan melihat berbagai uraian di atas, tulisan ini bertujuan untuk menggambarkan manajemen perubahan yang telah diterapkan oleh Pemerintah Provinsi Jawa Tengah dalam melakukan seleksi terbuka Jabatan Pimpinan Tinggi sebagai pimpinan organisasi publik. Tulisan ini diharapkan dapat memberikan pemikiran baru bagi ilmu administrasi publik, khususnya studi terkait organisasi dan manajemen perubahan.

\section{Metode Penelitian}

Penelitian ini menggunakan pendekatan post positivist dengan metode pengumpulan data studi literatur penelitian lapangan yang menghasilkan data primer dari wawancara dan catatan lapangan, dipadukan dengan literatur review terhadap berbagai laporan publikasi atau berita sebagai sumber data sekuder. Berita yang direviu sejumlah 50 buah dengan content yang mirip, menggunakan kata kunci "Talent Scouting Jateng". Pengamatan dilakukan karena peneliti berada di lingkungan perubahan yang terjadi dimana bisa mencatat proses perubahan mulai dari tahun 2014 hingga sekarang, ataupun catatan dari statement atau wawancara dengan BKD dan Sekda Prov. Jateng. Dengan melakukan studi ini, peneliti berharap mendapatkan kesimpulan pemikiran yang relevan untuk pembenahan kebijakan dan perubahan organisasi publik ke depan. Penulisan hasil disajikan secara deskripti, dengan pembahasan berdasarkan keterkaitan antar sumber data. Indikator yang menjadi bekal penelitian berdasarkan teori yang telah direviu di bawah ini.

Perubahan organisasi publik terdiri dari 5 (lima) segi menurut Pettigrew et.al (2001) dalam Kuipers et.al (2014), yakni : a) konteks (context), b) konten (content), c) proses (processes), d) kepemimpinan (leadership) dan e) hasil perubahan (outcome). Kelima segi ini dijelaskan oleh Kuipers (Kuipers et al., 2014) secara detail. Kelima segi perubahan ini menjadi titik tolak untuk mengkaji perubahan yang terjadi dalam menerapkan seleksi terbuka jabatan pimpinan tinggi di Pemerintah Provinsi Jawa Tengah.

Konteks (context), yaitu perubahan dengan melihat konteks mengacu pada lingkungan eksternal dan internal organisasi, seperti lingkungan politik yang berubah atau pelembagaan organisasi publik. Konteks sangat terkait erat dengan politik demokrasi sebagai referensi atau latar belakang dan interaksi perubahan yang terjadi (Kuipers et al., 2014). Sedangkan konteks yang menjadi latar belakang perubahan berupa kekuatan sosial ekonomi, karakteristik sistem politik, 
pengambilan keputusan elit mengenai keinginan dan kelayakan perubahan, serta terjadinya peristiwa perubahan seperti skandal dan karakteristik sistem administrasi (Kuipers, et.al, 2014).

Konten (content), yaitu perubahan organisasi dilihat dari isi/konten perubahannya termasuk strategi, struktur, dan sistem organisasi. Paradigma perubahan konten ini hampir serupa dengan pergeseran paradigm administrasi New Public Management ke Public Service. Kuipers (Kuipers et al., 2014) membedakan 3 (tiga) urutan perubahan dimana dalam masingmasing urutan perubahan menunjukkan konten yang berbeda berkaitan dengan tujuan perubahan organisasi dan bagaimana tingkat perhatian terhadap perubahan (what the change is about) atau bagaimana konten diimplementasikan (process). Ketiga urutan tersebut adalah a) perubahan tingkat pertama berkaitan dengan perubahan yang terjadi pada seluruh sektor namun tidak mengubah organisasi atau sektor secara keseluruhan, b) perubahan tingkat kedua yaitu berkaitan dengan budaya organisasi, iklim dan faktor perilaku lainnya, c) perubahan tingkat ketiga terkait dengan isi reformasi atau perubahan kebijakan.

Proses (processes), dalam Kuipers, et.al pendekatan terhadap perubahan organisasi publik dapat dibedakan dalam 3 (tiga) hal yaitu 1) proses yang direncanakan versus proses perubahan yang muncul (planned versus emergent change process), 2) resistensi terhadap perubahan (resistance to change) dan 3) faktor-faktor yang menentukan keberhasilan atau kegagalan implementasi perubahan (factor defining the success or failure of the change implementation). Dalam pendekatan planned versus emergent change, Wollmann (2000) melihat perubahan di sektor publik sebagai pertukaran antara gelombang reformasi (radikal) dan inkrementalisme yang terputusputus. William N Dunn dan Kuipers (Dunn, 2003; Kuipers et al., 2014) juga menemukan kurangnya intervensi atau campur tangan oleh tingkat pemerintahan yang lebih tinggi menjadi syarat untuk perubahan yang berhasil.

Kepemimpinan (leadership), para ahli memberikan pendapat yang berbeda-beda dalam melihat perubahan dikaitkan dengan kepemimpinan. Christensen (Kuipers et al., 2014) menekankan pada aspek pemimpin publik sebagai bagian dari politik sehingga berbeda dengan pemimpin pada organisasi privat, karena harus bertangganggungjawab pada pemilihnya (rakyat), sedangkan pemimpin organisasi privat bertanggungjawa pada dewan yang berasal dari pemegang saham. Perubahan dalam organisasi sektor publik menyebabkan perubahan dalam hubungan antara warga negara dan organisasi publik, di satu sisi politisi harus peka terhadap keinginan warga negara melalui rantai pemerintahan pemilihan, di sisi lain warga negara sebagai pengguna dan klien dapat meminta 
pertanggungjawaban politisi secara langsung untuk menyediakan layanan. Dengan demikian pemimpin politik memegang peranan yang sangat penting dalam proses perubahan organisasi (Kuipers et al., 2014). Pendapat lain disampaikan oleh Gabris (Gabris et al., 2001) yang menekankan bahwa kebutuhan kepemimpinan menjadi kredibel, sehingga keterlibatan dari manajemen puncak dan politisi sangat diperlukan.

Kavanagh dan Askkanasy menyimpulkan bahwa pemimpin harus kompeten dan dilatih dalam proses transformasi organisasi (Kuipers et al., 2014). Sementara pendapat Rusaw (Carol Rusaw, 2007) menyatakan bahwa diperlukan model kepemimpinan yang berbeda-beda sesuai pendekatan perubahan yang digunakan dalam suatu organisasi, yakni bisa berupa model kepemimpinan strategis-top down untuk model means-end, desentralisasi untuk model inkremental, berbagi (shared) untuk model pluralist dan kepemimpinan sendiri (self) untuk model individualbased.

Hasil (outcome), yakni melihat perubahan dari segi hasil. Kuipers (Kuipers et al., 2014) berpendapat bahwa hasil perubahan dapat dilihat dari jenis perubahan yang terjadi, jika perubahannya tergolong dalam perubahan yang direncanakan (planned change approach) maka hasil yang diinginkan telah ditetapkan terlebih dulu, sementara jika perubahannya tergolong dalam perubahan yang muncul (emergent change approach) maka hasil perubahan tidak ditentukan sebelumnya dan hasil muncul sebagai perubahan itu sendiri. Armenakis \& Bedeian menilai bahwa upaya perubahan organisasi menggunakan kriteria afektif dan perilaku. Keberhasilan perubahan pasti membutuhkan dorongan individu untuk memberlakukan perilaku baru sehingga perubahan yang diinginkan tercapai (Kuipers et al., 2014).

\section{Hasil dan Pembahasan}

Konteks perubahan terkait erat dengan dinamika politis. Seleksi terbuka merupakan program utama yang diusung Gubernur Ganjar sebagai bagian dari reformasi birokrasi. Dengan demikian pasca dilantik tahun 2013, kebijakan seleksi terbuka sebagai bagian obyektivitas memilih jabatan eselon aparatur diterapkan. Eselon III (administrator) dan eselon IV (pengawas) adalah jabatan yang paling banyak dilakukan lelang jabatan secara terbuka. Keduanya menggunakan prinsip seleksi terbuka, obyektif, dan bertahap melalui mekanisme talent pool.

$\begin{array}{ccr}\text { Talent } & \text { pool } & \text { yang } \\ \text { diselenggarakan } & \text { oleh } & \text { Pemprov. }\end{array}$ Jateng didasari dengan Surat Edaran Kemenpan RB Nomor 16 Tahun 2012 (Surat Edaran Kemenpan RB Nomor 16 Tahun 2012, 2012) yang merujuk pada UU Nomor 43 Tahun 1999 tentang Perubahan atas UU Nomor13 tahun 1974 tentang Pokok-pokok Kepegawaian (Undang Undang Nomor 43 Tahun 1999 Tentang 
Perubahan Atas UU Nomor 13 Tahun 1974 Tentang Pokok Pokok Kepegawaian, 1999).

Talent pool pada dasarnya merupakan kader potensial hasil dari proses talent scouting sebagai kandidiat yang dapat dipertimbangkan untuk dipromosikan jabatan eselon III dan eselon IV. Talent pool dipergunakan sebagai pertimbangan bagi ASN yang akan dipromosikan dengan dasar hasil tes kompetensi, penilaian kinerja, rekam jejak jabatan serta integritas.

Kebijakan yang mendasari pemberlakukan talent pool adalah beberapa regulasi tentang kepegawaian. UU Nomor 5 tahun 2014 tentang ASN (Undang Undang Nomor 5 Tahun 2014 Tentang Aparatur Sipil Negara, 2014) yang sebenarnya mengganti UU Kepegawaian hanya mengatur tentang promosi yang dilakukan secara obyektif, terbuka, dan dilakukan oleh tim penilai kinerja yang ditunjuk oleh Pejabat Yang Berwenang (PyB). Sedangkan kejelasannya baru terbit sejak tahun 2016.

Pasal 100 PP 18 Tahun 2016 tentang Perangkat Daerah (Peraturan Pemerintah RI Nomor 18 Tahun 2016 Tentang Perangkat Daerah, 2016) menjelaskan pembinaan dan pengisian jabatan pada perangkat daerah dilakukan dengan system merit. Sistem Merit dijelaskan lebih lanjut pada PP 17 Tahun 2017 tentang Manajemen PNS (Peraturan
Pemerintah RI Nomor 17 Tahun 2017 Tentang Manajemen PNS, 2017).

Menteri Pendayagunaan Aparatur Negara dan Reformasi Birokrasi (PANRB) Asman Abnur pada 20 September 2016 lalu telah menandatangani Surat Edaran (SE) Nomor B/3116/M.PANRB/09/2016 tentang Pengisian Jabatan Pimpinan Tinggi (JPT) di Lingkungan Pemerintah Provinsi (Pemprov) dan Pemerintah (Pemkab)/Kota (Pemkot) terkait dengan Pelaksanaan Peraturan Pemerintah Nomor 18 Tahun 2016 tentang Perangkat Daerah (Surat Edaran (SE) Nomor B/3116/M.PANRB/09/2016 Tentang Pengisian Jabatan Pimpinan Tinggi (JPT) Di Lingkungan Pemerintah Provinsi (Pemprov) Dan Pemerintah Kabupaten (Pemkab)/Kota (Pemkot), 2016). Dalam petunjuk teknis ini telah disebutkan bahwa pengisian jabatan lowong menggunakan seleksi terbuka, sedangkan pemindahan jabatan dari organisasi satu ke organisasi lain dilakukan dengan job fit. Berita ini dilansir di laman resmi secretariat kabinet RI sehingga menyiratkan bahwa seleksi dan konsep terbuka menjadi nafas penting pola promosi.

Dalam PP 11 Tahun 2017 tentang Manajemen PNS disebutkan tentang seleksi terbuka yang semakin menguatkan tentang PP Nomor 18 tahun 2016 (Peraturan Pemerintah RI Nomor 18 Tahun 2016 Tentang Perangkat Daerah, 2016). Mekanisme dan pengisian Jabatan Pimpinan Tinggi (JPT) ataupun jabatan lain 
termasuk administrator dan pengawas, melalui proses seleksi terbuka atau system merit. Namun di era Jokowi tahap II, terjadi penyempurnaan PP ini.

PP 17 tahun 2020 tentang Perubahan Atas PP 11 tahun 2017 tentang Manajemen PNS menyebutkan bahwa untuk pemenuhan kebutuhan organisasi dan pengembangan karier PNS, pengisian JPT melalui mutasi dari satu JPT ke JPT yang lain dapat dilakukan dalam satu instansi dan antar instansi melalui uji kompetensi sesuai dengan persyaratan dan ketentuan peraturan perundangundangan (Peraturan Pemerintah RI Nomor 17 Tahun 2020 Tentang Perubahan Atas PP 11 Tahun 2017 Tentang Manajemen PNS, 2020).

Selain JPT, sebagai jaminan karier PNS yang ditugaskan, dalam PP 17 tahun 2020 tentang Perubahan Atas PP 11 tahun 2017 tentang Manajemen PNS diatur kembali terkait dengan ketentuan batas usia pensiun pejabat fungsional yang diberhentikan sementara. Lebih lanjut, selain mutasi dan/ atau promosi, pengembangan karier juga dapat dilakukan melalui penugasan lingkungan instansi pemerintah atau di luar instansi pemerintah yang dilaksanakan dalam rangka optimalisasi pelaksanaan tugas dan pencapaian kinerja organisasi.

Secara kontekstual, kebijakan resmi yang berbentuk regulasi tentang talent pool belum diterbikan oleh pemerintah pusat. Jika melihat bahwa seleksi terbuka di Pemerintah
Provinsi Jawa Tengah telah berlansung sejak 2014, menyiratkan bahwa kebijakan tersebut murni dari ketetapan political will pemimpin daerah, yaitu Gubernur Ganjar, karena dasar regulasi yang mengaturnya belum ada ketika itu. Gubernur masih menggunakan deskresi dengan aturan lama, yaitu UU Nomor 22 Tahun 2004 tentang Pemerintah Daerah yang mengatur wewenang kepala daerah dalam menentukan struktur dan pengisian jabatan, serta UU 43 Tahun 199 tentang Perubahan atas UU Nomor 8 Tahun 1974 tentang Pokok-Pokok Kepegawaian. Meskipun saat itu sudah terbit UU baru tentang ASN namun Peraturan Pemerintah belum terbit sebagai petunjuk pelaksanaan.

Ketika sebuah keputusan dari pemimpin politis ditetapkan, maka sebisa mungkin harus dilaksanakan. Ketentuan tentang lelang jabatan, seleksi terbuka maupun promosi terbuka memiliki konteks sebagai tekad politik pemimpin daerah, sehingga ketika ditetapkan tetap diterapkan. Dengan demikian dari segi konteks, perubahan system pemilihan pejabat tinggi tidaklah begitu bermasalah.

Tahun 2015 hingga saat ini, prinsip lelang jabatan menggunakan konsep talent scouting dan talent pool sudah diperbarui dan menyesuaikan dengan ketentuan tentang ASN dari regulasi yang baru. Pembaruan terkait dengan content atau strategi.

Terkait dengan content yang menjadi bahasan pokok adalah 
strategi yang digunakan. Membahas tentang strategi tentu membahas tentang prosedur pelaksanaan seleksi terbuka. Pada tahap I seleksi terbuka yang dilaksanakan tahun 2014, system yang dipergunakan masih memang terbuka. Namun dari hasil pengamatan terdapat beberapa hal yang bersifat tertutup, atau bisa disebut semi closed.

Talent pool adalah wadah atau daftar nominasi calon pejabat, sedangkan talent scouting adalah konsep pencarian atau seleksi untuk mengisi daftar tersebut. Jika jaman dahulu terkenal dengan istilah DUK (Daftar Urut Kepangkatan) saat ini konsep seleksi lebih dikedepankan.

Strategi pertama dalam talent scouting era 2014 secara singkat yaitu : 1) pengumuman online untuk PNS dengan pangkat minimal III/c bagi pengawas dan yang sudah mengikuti diklatpim IV bagi administrator, 2) seleksi administrasi melalui pendaftaran online, 3) penyusunan makalah yang akan dinilai oleh pimpinan SKPD masingmasing dan dilaporkan kepada Tim Penilai Kinerja, 4) fit and proper test yaitu wawancara dengan pimpinan SKPD masing-masing dan didampingi BKD, 5) assessment centre melalui tes psikologi dan evaluasi kinerja, 7) hasil diumumkan melalui SKPD masing-masing. Dari model recruitmen seperti ini, banyak peserta yang lolos karena penguji adalah atasan / pimpinan SKPD masing-masing, namun ada beberapa SKPD yang tidak meloloskan pegawainya sama sekali.
Tahun 2015 strategi talent scouting berbeda dan berkembang. Untuk tahap 1) pengumuman dan syarat kepangkatan dan diklatpim masih sama, 2) seleksi administrasi dan pendaftaran online juga masih sama. Bagi yang lolos tahap berikutnya kemudian mengikuti 3) penyusunan makalah secara langsung tertulis di ruang ujian dan tidak boleh menggunakan buku atau catatan panduan. Penyusunan makalah dibagi dalam beberapa tema dan diberi waktu maksimal 120 menit. Makalah dinilai oleh tim dari perguruan tinggi sebagai juri. 4) bagi yang lolos tes makalah kemudian mengikuti 4) fit and proper test yang berisi tes wawancara, tes psikologi dan tes dinamika kelompok, 5) evaluasi kinerja, 6) hasil diumumkan secara online di website berupa nama yang lolos memenuhi syarat talent pool. Tahun 2016 masih menggunakan pola ini.

Pada tahun 2017 hingga 2019 terdapat pembaharuan talent scouting. Bagi pendaftar untuk calon pengawas/eselon IV minimal pangkat harus III/b terhitung mulai 2 tahun masa kerja. Sedangkan untuk administrator masih sama harus mengikuti diklatpim. Namun pada kesempatan ini juga diumumkan bahwa bagi Jabatan Fungsional Tertentu (JFT) tidak wajib mengikuti talent scouting sebagai syarat pengangkatan ke jenjang eselon III ataupun IV. JFT dianggap setara dengan talent scouting dan otomatis kandidat dalam talent pool. Ketentuan inilah yang menyebabkan banyak fungsional seperti Kepala 
BPPD, Kepala Dinas Pendidikan berasal dari JFT.

Strategi tersebut diimplementasikan dalam proses yang bertahap. Setiap proses talent scouting memakan waktu hingga 3 bulan rata - rata. Dimulai dari scanning data kepegawaian untuk menentukan daftar nominative peserta talent scouting berdasarkan pangkat dan golongan lalu diumumkan secara online. Proses selanjutnya adalah pendaftaran mandiri oleh peserta nominative melalui laman website. Petugas seleksi akan menscreening pendaftaran yang masuk dengan data nominative yang diumumkan sebelumnya. Jika terdapat ketidaksesuaian atau bagi pendaftar baru yang tidak ada dalam data nominative bisa mengurus di BKD. Di awal penyelenggaraan atau tahun 2014 proses ini sangat sederhana dan masih manual. Setelah selesai proses pengumuman cetak kartu ujian. Cetak kartu ujian ini diterapkan sejak talent scouting tahun 2015.

Pelaksanaan tahun 2014 telah jelas dengan prinsip sederhana. Setelah peserta dinyatakan lolos administrasi, ujian makalah dilakukan dengan penilai tim dan pimpinan masing-masing. Ujian fit propher juga demikian hingga berujung pada rekomendasi ke tim penilai kinerja dan hasil diumumkan. Namun sejak 2015 terdapat perbedaan implementasi ujian makalah dan kelanjutannya.

Proses penulisan makalah dilaksanakan di gedung PRPP yang langsung mengundang ratusan calon peserta untuk mengikuti ujian. Tim BKD bertugas sebagai penanggungjawab dan pengampu tes. Tes menggunakan metode tulis tangan tanpa contekan. Tahun 2019 tes sudah menggunakan computer dan diselenggarakan di ruang khusus. Hasil makalah dinilai oleh tim yang telah ditunjuk oleh pemerintah daerah. Tim terdiri dari akademisi beragam jurusan, terutama jurusan administrasi publik/manajemen kebijakan publik ataupun lainnya, yang berasal dari perguruan tinggi di Jawa Tengah, seperti Universitas Diponegoro, Universitas Negeri Semarang bahkan Universitas Gajahmada. Hasil yang lolos ujian makalah diumumkan di website untuk mengikuti tahapan ujian selanjutnya.

Ujian selanjutnya yaitu psikotes, wawancara kompetensi, hingga ujian dinamika kelompok/diskusi diselenggarakan oleh Tim accessor dari BKD Jateng dan akademisi. Hasil tes berupa memenuhi syarat atau tidak. Hasilnya kemudian disampaikan kepada Tim Penilai Kinerja untuk menentukan lolos dan tidaknya dalam talent pool.

Dari talent scouting selama ini, mayoritas peserta lolos memenuhi syarat masuk dalam talent pool. Hanya beberapa dan tidak sampai $25 \%$ yang tidak lolos. Bahkan untuk tahun 2018 konsep tes juga menyelenggarakan ujian ulang atau kalau disekolah dikenal dengan system remidi. 
Hasil talent scouting berupa Data talent pool inilah yang menjadi bahan pertimbangan untuk pengangkatan eselon III dan eselon IV berikutnya. Hasil talent pool diambil sebagai bahan kebijakan untuk menentukan promosi seseorang. Sejak 2015 hingga 2019 telah dilantik ratusan jabatan eselon III dan IV. Namun tentu saja ada riak yang mengganjal. Pelantikan pada tahun 2014 sempat mendapatkan sanggahan dari peserta hingga berujung pada proses di PTUN. Namun demikian, kasus tersebut tetap dimenangkan oleh pemerintah. Proses sengketa lain belum ada, namun berdasarkan hasil pengamatan terdapat beberapa hal yang belum terbuka dalam konsep talent pool menuju pelantikan.

Hal yang belum terbuka antara lain terkait, peserta yang lolos talent pool dari tahun 2015 masih ada yang belum dilantik/diangkat sebagai pejabat eselon III ataupun eselon IV. Namun justru peserta talent pool tahun 2018 sudah dilantik. Meskipun banyak desas-desus yang beredar bahwa ada pejabat yang dilantik tidak dengan dasar talent pool, namun hal tersebut tidak bisa menjadi data valid karena sebagian dari peserta yang merasa dirugikan enggan untuk memberitahu. Hasil inilah yang menjadi bahan pembahasan yang hangat.

Melihat konsep manajemen perubahan sektor publik khususnya terkait promosi jabatan eselon mungkin tidak terlalu menarik bagi masyarakat. Tetapi bagi lingkungan birokrasi, bagi pengamat dan bagi akademisi akan sangat menarik dinamika didalamnya. Berdasarkan lima kategori, context, content, process, leadership dan outcome dapat diketahui jelas bagaimana arah perubahan yang terjadi.

Talent scouting untuk promosi jabatan eselon III dan eselon IV di Jawa Tengah pada dasarnya adalah sebuah inovasi. Pada saat mulai tahun 2014 kontekstual hukum yang dipergunakan sebenarnya tidak relevan lagi, karena sudah terbit aturan baru tentang regulasi ASN meskipun peraturan pelaksanaannya belum terbit. Dengan kata lain, pelaksanaan Talent Scouting tersebut merupakan hasil dari inovasi dan gagasan leadership/kepemimpinan.

Tekad Gubernur dan Wakil Gubernur yang baru dilantik untuk menjalankan reformasi birokrasi merupakan modal utama. Keberanian inilah yang bisa disebut sebagai deskresi dalam kebijakan publik. Tanpa tekad pemimpin yang kuat, konsep talent scouting tidak berjalan, maka tak salah jika dan Gabris (Gabris et al., 2001) menekankan perlunya pemimpin yang kredibel untuk sebuah perubahan.

Sedangkan strategi atau content perubahan pada talent scouting ini dapat dibedakan dalam 4 (empat) periode. Periode I di awal penyelenggaraan atau tahun 2013/2014, Periode II di tahun 20152016, dan periode III di tahun 2017 2018, Periode IV di tahun 2019. Perbedaan mendasar strategi nya adalah pada Periode I menggunakan tim penilai kinerja dari BKD dan pimpinan SKPD masing-masing, 
sehingga ujian dan penentu lolos tidak tergantung dari pimpinan SKPD masing-masing. Periode II hingga periode IV sudah menggunakan kerjasama akademisi dan accesor sebagai pengampu tes/ujian (Parwito, 2014). Lebih ke arah teknis, periode II hingga periode III tes makalah dengan tulis tangan, periode IV lebih ke komputerisasi, namun ketiganya menggunakan pengumuman dan penggunaan IT yang lebih luas. Perkembangan strategi ini tak ayal merupakan bentuk perubahan yang signifikan terhadap pola promosi yang telah ada sebelumnya dengan badan pertimbangan jabatan dan kepangkatan (Baperjakat) secara tertutup dengan model terbuka menuju system merit.

Implementasi strategi tersebut sedikit berubah, terutama soal persyaratan peserta. Pada awalnya calon peserta eselon IV/pengawas hanya bisa diikuti oleh minimal PNS III/c, namun kemudian bisa diikuti oleh III/b masa kerja 2 (dua) tahun minimal. Sedangkan untuk JFT yang semula tidak dijelaskan kemudian dijelaskan bahwa tidak wajib mengikuti talent scouting untuk menduduki jabatan eselon III dan eselon IV. Sebenarnya implementasi proses ini menuju pada kesesuain dengan regulasi yang sebenarnya. Regulasi juga mengatur minimal jabatan eselon IV adalah III/b dan seorang JFT juga bisa menjabat structural tanpa tes lagi bila dianggap berkompeten. Yang menjadi tanda tanya besar adalah mengapa pada awal atau sejak 2014-2016 ketentuan calon pesertanya dibuat lain. Dengan demikian indikasi syarat ketentuan calon peserta terdapat penyimpangan, indikasi inilah yang berimbas pada hasil.

Hasil talent scouting atau talent pool tidak optimal dipergunakan, terbukti dengan peserta yang lolos tahun 2015 masih kalah bersaing dengan peserta yang lolos tahun 2018, ketika dilantik menjabat. Bahkan pelantikan pejabat hasil lelang pernah mendapatkan gugatan PTUN (PTUN Tolak Gugatan Hasil Lelang Jabatan Kepsek Mantan Guru Teriak Histeris, 2014).

Gugatan PTUN yang muncul bukan hanya merupakan ketidakpuasan pribadi, tetapi juga sebagai resistensi perubahan. Jika mengesampingkan kepentingan pribadi, resisten ini sebenarnya menolak keputusan karena dianggap sebagai hal yang bertentangan dengan norma yang legal, sebagaimana pendapat Agocs (Gabris et al., 2001). Dan pada dasarnya PTUN justru menjadi resistensi yang positif sebagaimana debat yang dilakukan oleh Robbin (Gabris et al., 2001) karena memberikan masukan untuk perbaikan perubahan ke depan.

Antara talent pool dan pengangkatan jabatan kurang adanya ikatan. Ketika peserta yang lolos tidak kunjung dilantik maka yang bersangkutan harus mengikuti ujian ulang dalam kurun 4 (empat) tahun, dengan demikian terjadi pemborosan keuangan. Lebih baik, hasil talent pool yang ada dioptimalkan terlebih 
dahulu, dan ketika membutuhkan personal baru, bisa diselenggarakan talent scouting berikutnya. Proses dan hasil perubahan dari talent scouting yang perlu dibenahi adalah tidak perlu dilakukan setiap tahun jika kebutuhan pengangkatan tidak ada. Bahkan tidak perlu ada remidi/ujian ulang khusus untuk yang kurang memenuhi syarat. Karena jika talent scouting terus menerus dilakukan maka hampir seluruh pegawai dengan golongan III/b ke atas pasti pada akhirnya masuk talent pool. Jika data talent pool membengkak, maka sifat kompetisi dan profesionalitas juga akan kabur, dengan kata lain, pemilihan pengangkatan pejabat akan menjadi seperti semula ketika tidak ada talent pool, karena semua sudah pada status yang sama.

Imbas dari hasil ini adalah munculnya ketidakpercayaan terhadap kinerja Tim Penilai Kinerja. Tim Penilai Kinerja menentukan peserta talent scouting lolos dan tidak berdasarkan hasil tes, namun bagamaina dengan pelantikan pejabat. Berdasarkan ketentuan pada UU ASN, Tim Penilai Kinerja yang ditunjuk oleh Pejabat yang Berwenang (PyB) atau Sekretaris Daerah. Dari penyimpangan ini terdapat 2 (dua) kemungkinan, yaitu Tim Penilai Kinerja untuk talent scouting tidak sama dan tidak sinergis dengan tim penilai kinerja yang menentukan promosi/pengangkatan jabatan, atau munculnya subyektivitas dari pihak tertentu. Mengingat birokrasi sangat dekat dengan lingkungan politik, tak ayal subyektivitas atau tekanan menjadi indikasi kuat pengambilan keputusan, sebagaimana kata Ridder et al. (2005).

Dari proses talent scouting, hasil lolos dan tidaknya peserta diumumkan terbuka sejak tahun 2015. Namun demikian tidak ada indikasi pengumuman scoring atau system merit yang dipergunakan untuk menilai seseorang layak tidak untuk jabatan tertentu. Tim Penguji berdalih bahwa berdasarkan UU Nomor 14 Tahun 2008 tentang Keterbukaan Informasi Publik, hasil pengukuran kapabilitas, intelektualitas dan rekomendasi kemampuan seseorang (peserta tes) merupakan informasi yang rahasia, sehingga disampaikan secara tertutup kepada ASN yang bersangkutan dan atasan langsung, tidak untuk dipublikasikan secara umum. Namun jika melihat tes CPNS beberapa periode, score tes masingmasing peserta terpampang jelas didepan publik. Jadi melihat konteks informasi yang dikecualikan perlu dibenahi oleh seluruh tim penilai. Jika mempertimbangkan manfaat nya, keterbukaan scor talent scouting justru akan menunjukkan obyektivitas dan mengikis subyektivitas. Ketika peserta dengan score rendah dilantik dan mengalahkan peserta dengan score tinggi, hal tersebut bisa diketahui sehingga obyektivitas terjaga. Namun bila ditutupi untuk maksud tertentu lain halnya.

Pemprov. Jateng bisa mencontoh konsep evaluasi merit pada system pengadaan barang dan 
jasa pemerintah. Dalam regulasi pengadaan barang dan jasa ada model evaluasi system merit yang memberikan bobot penilian berbeda pada setiap kriteria peserta. Dengan demikian bisa saja peserta yang makalahnya nilai jelek, tetapi unggul dalam wawancara masih bisa bersaing dengan yang nilainya sebaliknya. Untuk itu, kriteris bobot penilian juga ditentukan bagi masingmasing jabatan yang lowong, sehingga bisa dikolaborasikan dengan kriteria dari talent scouting.

\section{Kesimpulan}

Manajemen perubahan pada pemerintah daerah, khususnya pelaksanaan talent scouting untuk promosi jabatan eselon III dan eselon IV di Pemprov. Jateng telah berlangsung sejak 2014. Perubahan terjadi karena leadership yang kuat, content yang terus disempurnakan menyesuaikan context regulasi yang ada, namun pada proses dan hasil masih perlu adanya sinergitas pelaksanaan dengan pola pengangkatan jabatan eselon III dan IV. Perubahan model promosi jabatan harus inline dengan perubahan model pengangkatan jabatan. Dengan demikian perubahan yang digagas akan mencapai visi dan sesuai dengan pola perubahan yang lain.

\section{Acknowledgment}

Penelitian ini merupakan swadaya kelompok. Hasil penelitian diharapkan memberikan sumbang sih dan memperkaya kasanah ilmu administrasi publik, khususnya pada diskusi - diskusi akademik di Universitas Diponegoro. Selain itu semoga kajian ini bisa menjadi rujukan atau bahan formulasi kebijakan pada Pemerintah Provinsi Jawa Tengah.

\section{Referensi}

Armenakis, A. A., \& Bedeian, A. G. (1999). Organizational change: A review of theory and research in the 1990s. Journal of Management, 25(3), 293-315. https://doi.org/10.1177/01492 0639902500303

Aykac, B., \& Metin, H. (2012). The Future of Public Organizations. Procedia - Social and Behavioral Sciences, 62, 468-472. https://doi.org/10.1016/j.sbspr o.2012.09.077

Carol Rusaw, A. (2007). Changing Public Organizations: Four Approaches. International Journal of Public Administration, 30(3), 347-361. https://doi.org/10.1080/01900 690601117853

Cunningham, J. B., \& Kempling, J. S. (2009). Implementing change in public sector organizations. Management Decision, 47(2), 330-344. https://doi.org/10.1108/00251 740910938948

Dunn, W. N. (2003). Pengantar Analisis Kebijakan Publik (S. Wibawa (Ed.); 2nd ed.). Gajah Mada University Press.

Gabris, G. T., Golembiewski, R. T., \& Ihrke, D. M. (2001). Leadership Credibility, Board Relations, and Administrative Innovation at the Local Government Level. Journal of Public Administration Research and Theory, 11(1), 89-108. 
https://doi.org/10.1093/oxfordj ournals.jpart.a003496

Kuipers, B. S., Higgs, M., Kickert, W., Tummers, L., Grandia, J., \& Van Der Voet, J. (2014). The management of change in public organizations: A literature review. Public Administration, 92(1), $\quad 1-20$. https://doi.org/10.1111/padm.1 2040

Parwito. (2014, November 5). Libatkan Akademisi Ganjar Lelang 5 Kursi Jabatan Pemprov Jateng. Www.Merdeka.Com. https://www.merdeka.com/peri stiwa/libatkan-akademisiganjar-lelang-5-kursi-jabatanpemprov-jateng.html

Peraturan Pemerintah RI Nomor 17 Tahun 2017 tentang Manajemen PNS, Pub. L. No. 17 (2017).

Peraturan Pemerintah RI Nomor 17 Tahun 2020 tentang Perubahan Atas PP 11 Tahun 2017 tentang Manajemen PNS, Pub. L. No. 17 (2020).

Peraturan Pemerintah RI Nomor 18 Tahun 2016 tentang Perangkat Daerah, (2016).

PTUN Tolak Gugatan Hasil Lelang Jabatan Kepsek Mantan Guru Teriak Histeris. (2014). News.Detik.Com. https://news.detik.com/berita/2 660998/ptun-tolak-gugatanhasil-lelang-jabatan-kepsekmantan-guru-teriakhisteris/komentar

Rusaw, A. C. (2005). Transforming the Character of Public Organizations: Techniques. 262.
Stephen P Robbins, T. A. J. (2013). Organizational Behaviour (S. Yagan (Ed.); 15th ed.). Pearson.

$\begin{array}{lll}\text { Surat } & \text { Edaran } & \text { (SE) Nomor } \\ \text { B/3116/M.PANRB/09/2016 } \\ \text { tentang } & \text { Pengisian Jabatan } \\ \text { Pimpinan } & \text { Tinggi (JPT) di } \\ \text { Lingkungan } & \text { Pemerintah Provinsi } \\ \text { (Pemprov) } & \text { dan Pemerintah } \\ \text { Kabupaten } & \text { (Pemkab)/Kota } \\ \text { (Pemkot), } & \text { Pub. L. } & \text { No. } \\ \text { B/3116/M.PANRB } / 09 / 2016 \\ \text { (2016). }\end{array}$

Surat Edaran Kemenpan RB Nomor 16 Tahun 2012, (2012).

Tom Christensen, Per Laegreid, Paul G Roness, K. A. R. (2007). Organization Theory and the Public Sector Instrumen, culture and myth. Routledge.

Undang Undang Nomor 43 Tahun 1999 tentang Perubahan Atas UU Nomor 13 Tahun 1974 tentang Pokok Pokok Kepegawaian, (1999).

Undang Undang Nomor 5 Tahun 2014 tentang Aparatur Sipil Negara, (2014).

Wibowo, G., \& Soeprihattanto. (2020). MANAJEMEN INOVASI : PROMOSI DALAM MENDUKUNG SISTEM MERIT DI BKD PROVINSI JAWA BARAT Galih. 2, 1-10. 